\title{
The Separately Housed Undergraduate Library
}

The development of the separately housed undergraduate library on the modern university campus is a recent innovation. As the university library became larger and more complex and more emphasis was placed on graduate education, the separately housed undergraduate library developed as a solution to some of the problems caused by size and shift in emphasis. The separately housed undergraduate library differs from the traditional university library in six ways: (1) by providing open access to the collection; (2) by centralizing and simplifying services to the undergraduate; (3) by providing a collection of carefully selected books; (4) by attempting to make the library an instructional tool; (5) by providing services additional to those given by the research library; and (6) by constructing a building with the undergraduate's habits of use in mind.

$T_{\mathrm{H}}$ HE DEVELOPMENT of the separately housed undergraduate library on the modern university campus is a recent innovation. The interest in effective undergraduate education which led to the creation of these libraries, however, is not of such recent origin.

Most universities and their libraries were relatively small until this century. More important, they were largely undergraduate institutions. The great expansion of graduate education is a twentieth-century phenomenon. The problems of the undergraduate in using university collections were greatly compounded by the striking growth in the size of collections and an increasing emphasis on the acquisition of materials suitable for research.

The large university collections became increasingly difficult for the under-

Dr. Braden is Librarian for General Administration and Research in Ohio State University. graduate to use. If he were confronted with five drawers under "Shakespeare" or twenty-five under "United States," he was apt to be discouraged from beginning a search for what he wanted. If he had to select his books from the card catalog and obtain them through paging in a closed stack system, he might well abandon the attempt before finally locating a book which was not checked out, missing, or at the bindery-and which was suitable for his purposes. The university library was also frequently difficult to use because it was crowdedoften study conditions were unsatisfactory and staff was insufficient to handle the volume of work.

Arthur McAnally summed up the difficulties facing the undergraduate in his attempts to use university collections:

Books are not very accessible to the undergraduate and reserve room service, which was about all most of them got freely, was not very satisfactory educationally. Of 
course, the enterprising undergraduate could surmount the obstacles of huge card catalogs, impersonal circulation desks, etc. but he was discouraged at every hand. ${ }^{1}$

At the same time that university libraries were becoming more difficult for the undergraduate to use successfully, there was a change taking place in teaching methods which sent him to the library with greater frequency. Wider independent reading was being encouraged as teachers moved away from the traditional textbook/reserved book reading pattern. Thus the undergraduate was trapped by this double development: increasing emphasis on the use of the library at a time when the library was becoming increasingly difficult for him to use.

The first response to this problem was the development of the undergraduate collection housed in the main library. The University of Chicago and Columbia University founded early undergraduate collections. Many other universities have since adopted what might be called the "undergraduate plan." Examples are (or in some cases were) found at the University of New Mexico, University of Cincinnati, University of Illinois, University of Tennessee, Duke University, and Yale University. Many new libraries built in the past decade, some presently being built, and others in the planning stage incorporate the "undergraduate plan" in some form.

Most take the form of setting aside one or two floors of a new building for undergraduate purpose. Small institutions may only provide a large reading room. An undergraduate collection may be little more than a reserve collection for lower division students; it may be a browsing collection of light fiction, periodicals, and non-course-related materials; or it may be a "learning center" -a relatively small collection of books,

\footnotetext{
${ }^{1}$ Arthur M. McAnally, "Library Service to Undergraduates: A Symposium-Introductory Remarks," CRL, XIV (July 1953), 266.
}

some of which relate to the curriculum and some of which are of general interest.

With the constant growth of the central university collection, the increasing demand for service to graduate students and faculty, and the increasing inadequacy of the central library to handle these demands and resources, the undergraduate collection housed in the main building began to be viewed as an unsatisfactory solution to the undergraduate's problems, and the separately-housed undergraduate library on the university campus was advanced as a more satisfactory solution.

These separately housed libraries were to differ from the traditional university library in six ways:

1. By providing open access to the collection to avoid the difficulties of the closed stack system;

2. By centralizing and simplifying services to the undergraduates;

3. By providing a collection of carefully selected books, containing the titles all undergraduates should be exposed to for their liberal education, as well as incorporating the reserved book collection;

4. By attempting to make the library an instructional tool by planning it as a center for instruction in library use, to prepare undergraduates for using larger collections, and by staffing it with librarians interested in teaching the undergraduate the resources of a library and the means of tapping those resources;

5. By providing services additional to those given by the research library;

6. By constructing a building with the undergraduate's habits of use in mind.

The first of these changes-provision of open access to the collection (exclusive of some reserve books)-would allow the student to do his book selection directly from the shelves, rather than re- 
lying on the card catalog as his only approach to the collection. By surrounding the student with booksnot separating him from them-it was hoped that he would be encouraged to read more than assigned titles. Open access was envisaged as one of the most important contributions of the undergraduate library.

Second, centralization of services was intended to remove the obstacles which impede the undergraduate in his search for library materials, making the learning process easier and more satisfactory. It was hoped that the undergraduate library could bring together in one place all aspects of library service relating to the undergraduate curriculum, thereby encouraging the student to learn. The undergraduate would no longer be faced by a system in which he had to go one place to read reserve books, another to find materials for a term paper, a third to find avocational reading, and yet another to find a place to sit and read these materials. He would no longer face the dispersion of reserve materials among the main library and the several branch libraries. No longer was he to be discouraged by being subjected to the idiosyncrasies of a treasure hunt to find the books he needs. The needs of undergraduates and graduate students, it was increasingly felt, were vastly different; the two did not mix well. The undergraduate library would try to furnish a kind of service that was not possible in the large university library, and it would provide one place in which the undergraduate could do most of his work.

In addition, these centralized services would be simplified. Because the collection would be relatively small, the cata$\log$ which would confront the student would not be huge and forbidding. Likewise, there would not be so many books on any one subject that the student would become confused by the large array before him. The library staff would also be able to assist him more readily in the use of this smaller and more easily approachable collection.

Third, the undergraduate library was to house a carefully selected duplicate collection of books which would support the curriculum to provide a selection of the best writings of all times and all peoples. It was to attempt to satisfy the instructional needs and general reading interests of the undergraduate throughout his four years of college. Besides providing the general collection, the undergraduate library was to include the reserve books which are a part of the curriculum. But in no case was the undergraduate library thought of as satisfying only the needs of course assigned reading. It was seen as an "educational breakthrough in our universities . . . Its potential is far beyond the simple purposes of providing course assigned readings. ... Its real strength is in its provision for individual differences, it balance of overspecialization and its creation of a true learning climate."' Keyes Metcalf saw Lamont library's general collection as one of its greatest contributions.

Fourth, the undergraduate library was to serve as an instructional tool. It was envisaged as a workshop in which the undergraduate could learn on a relatively small scale those library skills which could later be applied to larger and more complex collections. The staff was seen as having a teaching function as one of its most important tasks. It was felt that the library should be "staffed by a group of librarians who have a keen interest and an understanding of undergraduate education."3

The card catalog was to be a tool used in teaching the student how to approach

\footnotetext{
${ }^{2}$ Louis Shores, "The Undergraduate and His $\mathrm{Li}-$ brary," in University of Tennessee Library Lectures, ed. by Lanelle Vandiver, No. 11 (Knoxville: University of Tennessee, 1960), p. 33.

${ }^{3}$ Interview with Stephen A. McCarthy, director of the University libraries, Cornell Universitv, October $20,196.5$.
} 
the collection. The same was true of the periodical indexes, the reference collection, and the vertical file which were also to be used as sources of information. The book collection itself was to be used to help mold student reading habits. The collection was to be a tool used to supplement and to implement the instructional program of the university. Thus the librarians were not primarily to help the student do his work, but to teach him how to do it; to lay a foundation on which the student could build in the future, not only during his college years, but in the years following his graduation.

Fifth, the undergraduate library was to embody something more than the traditional university library. Not only were there to be facilities for reading-books and chairs-but there were also to be facilities for listening to recordings, for holding meetings and discussions, for viewing art exhibits, and other activities. By combining various media from which to learn, the undergraduate library would afford the student a broader opportunity.
Sixth, the undergraduate library was to be designed and built with the express needs and habits of the undergraduate in mind. How, why, and when he uses the library were to dictate the character of the building. The building was to be conveniently located in terms of student habits. At some universities this would be interpreted as on the central campus near an important student traffic route. At other places, it was thought best to locate it near the student living quarters. In the design of the building, simplicity of layout was considered desirable.

These then are the aims of the separately housed undergraduate library on a university campus. Whether or not they have been achieved at institutions which have established undergraduate libraries has to be answered in terms of individual institutions. In most cases, however, the results were uniform enough to be able to assert that these criteria have been met although in varying degrees and with varying interpretations.

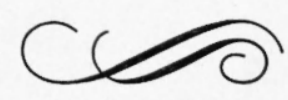

